\title{
TRAFFIC CENSUS AND ANALYSIS (A CASE STUDY)
}

\author{
Faheem Ahmed Malik ${ }^{1}$, Mansoor Ahmed Lone ${ }^{2}$, Riyaz Ahmed Qasab ${ }^{3}$, Misba Gul ${ }^{4}$ \\ ${ }^{1}$ Undergraduate B.Tech Student, Department of Civil Engineering, IUST Awantipora, J\&K India-192122 \\ malikfaheemahmed@gmail.com \\ +91-9419777676 \\ ${ }^{2}$ Undergraduate B.Tech Student, Department of Civil Engineering, IUST Awantipora, J\&K India-192122 \\ ${ }^{3}$ Assistant Professor, Department of Civil Engineering, IUST Awantipora J\&K India-192122 \\ ${ }^{4}$ Assistant Professor, Department of Civil Engineering , IUST Awantipora, J\&K India-192122
}

\begin{abstract}
Traffic Census is the baseline of Transportation Engineering. All management as well as engineering operations are done on the basis of this only. There is a considerable variations in flow, so for the purpose of designing averaging of these counts is done into single volume count. There are four main methods of Traffic Census namely Manual Method, Automatic Method, Combination of Manual and Automatic Method and Photographic Methods. All these have their pros and cons. These have different preferences with respect to Accuracy, ease of Documentation, Versatility and economics. Three main methods of Traffic Analysis IRC, U.K method and U.S.A practices have been discussed along with IOWA Department of Transport guidelines for measurement of Congestion. For better management of Traffic, duration of Survey as per IRC has to be increased as urban areas are moving from Developed to developing. Sanat Nagar/Rawalpora Intersection is the most important that is encountered in $17.8 \mathrm{~km}$ stretch of NH1A Bypass which is expected to be the jugular Vein of the Greater Srinagar City. It can be considered as a place where whole of Kashmir meets. A case study of Traffic Census and Analysis of the said intersection is presented.
\end{abstract}

Keywords: Traffic Census, Traffic Analysis, Transport

\section{INTRODUCTION}

John F Kennedy said "It was not our wealth that led to good Transport Infrastructure but our good Transport Infrastructure led to our wealth" Transportation and its allied problems are the phenomenon concerning all Road users in various forms and an effective remedy to these is necessary for the overall betterment of the society. Transportation should satisfy Safety, Rapidness, Comfort, Convenience and economic considerations as well as be Eco-Friendly.

"Srinagar, the capital of the state has to function as a place of pride for the people ofstate who look towards the city as a model city" ${ }^{[8]}$. With the proposal of Satellite Town of Greater Srinagar likely to Comprehend in very near future, National Highway 1A Bypass Stretching 17.8km's from Panthachowk-Shalteng will be the Jugular Vein of the City.Rawalpora Intersection is the most important intersection that is encountered in the $17.8 \mathrm{Km}$ Stretch of NH1A Bypass. It is a Four Armed at Grade junction which is at a Distance of 7,752meters from Athwajan from where NH1A Bypass starts and 10,048 meters from Shalteng where NH1A Bypass ends. It can be considered as the Intersection where whole of Kashmir meets. One side of the Intersection approaches South Kashmir from Athwajan where is the Second side Approaches North Kashmir via Hyderpora-Shalteng, whereas from third side it approaches to Central Business District LalChowk and Fourth Side meets the Army Airport i.e. Old Airprt

\subsection{Understanding the Problem}

In Transportation Engineering thing of primary importance is the measurement of Flow and then analysis of the same, be it in the form of Motorists, Cyclists, Passengers, Pedestrians, etc. A proper estimate is essential for a particular facility to function properly and give the requisite results. Overestimate leads to waste of resources. Underestimate leads to drop in L.O.S, congestion and allied effects.

\subsection{Need}

There are four Basic E's of Transportation Engineering namely, Engineering, Education, Enforcement and Emergency Response. Except for the education, Flow Measurement and Analysis are the pre-requisite for all the other E's. Level and type of Education also depends to some extent Flow Characteristics.

\section{WHY!!??}

- It is the baseline of Transportation Engineering.

- It serves as the Standard document for the further evaluation.

- Creation of Transport network for a new city is based on this only.

- Only based on Traffic Census an Intelligent Solution can be sought out of a Traffic Problem be it Congestion, lack of facilities, economy of time, diversion.

- All Traffic Management operations are done on the basis of this only e.g. Restriction on Entry, Loading 
Unloadingand Restriction on Parking, employment of number of officials for enforcement.

- Up gradation of Existing facilities.

- Used to determine critical flow time periods, influence of large vehicles or pedestrians on vehicular traffic flow.

- Helps in documentation of traffic volume trend.

Length of the sampling period depends type of count \& intended use of data recorded.

\subsection{Conflicts at Sanat Nagar/ Rawalpora}

\section{Intersection}

Any location having merging, diverging or crossing maneuvers of two vehicles is a potential Conflict Point. These are highly undesirable as these cause delay in Traffic and are major reason for all the accidents. The main aim of intersection Control is resolving these conflicts for ensuring safe as well as efficient movement of Traffic including Vehicles as well as Pedestrians.

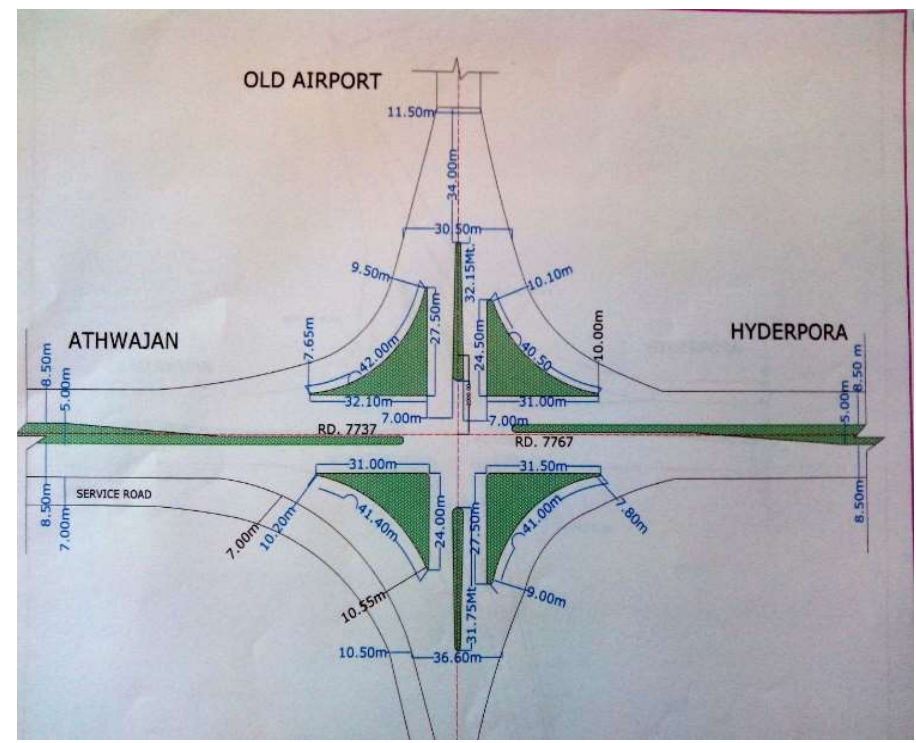

Fig 1: Drawing of Sanat Nagar/ Rawalpora Intersection.

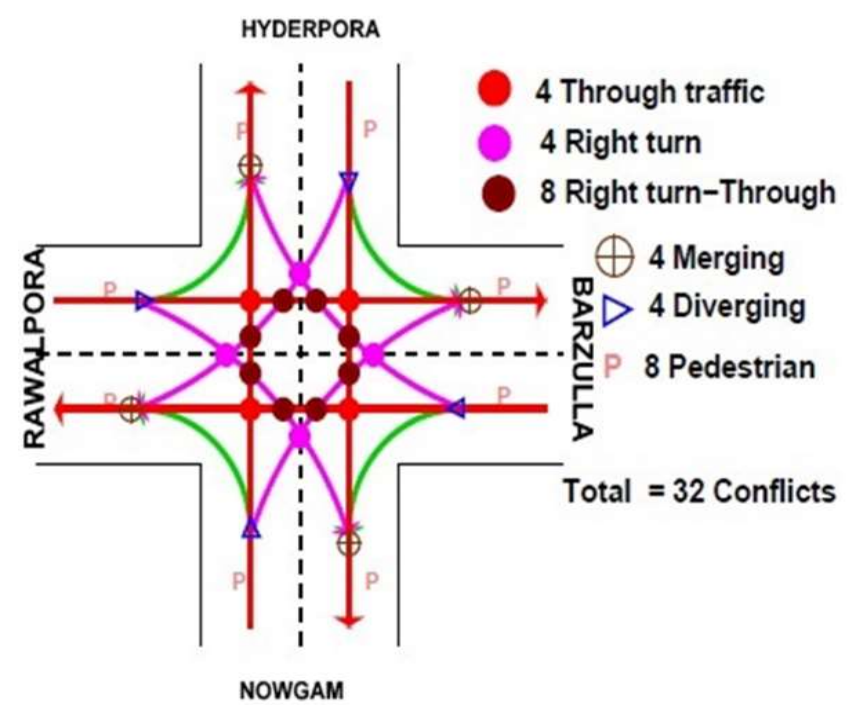

Fig 2: Conflicts at Sanat Nagar/ Rawalpora Intersection.
In the Present Scenario Conflicts for through traffic are 4, whereas for Right turn are 4. For Right turn through movement are 8. Merging \& Diverging Conflicts are 4 whereas Pedestrian Conflicts are. Therefore there are a total of 32 Conflicts.

\section{Identifying Major Conflict Problem}

The main wedlock at each Leg is created by through traffic, Right Turn, Diverging Traffic which merges at the same point due to which long queues are formed thereby disrupting the flow in all directions.

\section{METHODS OF TRAFFIC CENSUS}

\subsection{Manual Method [1]}

Manual methods use field personal to count and classify traffic flowing past a fixed point (Section). Number of enumerators needed to count the vehicle depends upon the number of lanes in highway on which count is to be taken, type and accuracy of information desired. IRC [2] recommends recording of data in each direction of travel separately and posting of observers for each direction. It is desirable to have literate enumerators with qualification preferably middle or matriculation. For keeping up the accuracy and maintaining precision the work is done in shifts, with adequate time given to each surveyor for rest as well as food and water.

\section{Method}

The data is recorded mostly in five Dash System in which vertical Strokes are entered for the first 4 vehicles which is followed by an Oblique stroke for the Fifth so as to represent a total of 5. Once an observer is familiar with this system, he tends to follow this is momentarily. It makes evaluation simple, hassle free with minimum of errors.

For examplefor Traffic entering a Four legged Intersection, is broken usually into three Categories viz a viz Left Turning, Right turning and Straight ahead Traffic. If the flow conditions are such that the percentage of U-turns is significant than they are also calculated.Traffic Enumerators are posted on each arm of the Intersection. IRC has prescribed the field data sheet ${ }^{[2]}$ for such flows.

\subsection{Automatic Methods}

Portable counters serve the same purpose as manual counts but with automatic counting equipment. The period of data collection using this method is usually longer than while using manual counts. For 24-hr census Automatic Methods have to be used.

\subsubsection{Mechanism}

Automatic methods consists of an equipment which serves the purpose of Traffic measurement in two steps:-

1. Detecting the passage or presence of a vehicle known as Detector or Sensor.

2. Recording the count. 
Sensors operate on following different principles, thus deriving the types of censors on the basis of operations only:-

1. Road Tube: - Also known as Pneumatic tube is a flexible tube in which one end is sealed is clamped to the road surface at right angles to the pavement, other end is connected to a diaphragm actuated switch. When an axle of vehicle crosses the tube, volume of air gets displaced which instantaneously sends the electric signal. Two such contacts actuated results in one count of the vehicle.

2. Electric Contact: - The Sensor equipment consists of a pair of steel strips contained in a rubber strip which is buried beneath the surface. On being pressed by the weight of a moving axle the Steel strips come in contact with each other, thus resulting in flow of electric current. It has an advantage that it is able to distinguish between different streams of traffic flow, otherwise there is no difference between Road tube and electric tube except for the mechanism.

3. Photo-electric: - On one end of the road is fixed with a source of light which emits a beam across the road, other end has a fixed Photo-cell which can distinguish between Light beam and absence of it. Passage of a traffic cause the obstruction, thereby causing a detection by photocell. It is also not able to distinguish between different lanes of flow.

4. Magnetic: -In this case magnetic disturbance caused in a magnetic field by passage of a vehicle is used as the basis of sensing. Magnetic field is provided by a coil buried beneath the surface of road.

After traffic is detected by a Sensor second part of an automatic Traffic Counting Device is the recording mechanism. Some of the common types are:-

1. Counting Register: - It is an accumulator counter indicating directly number of vehicles on a meter just like the number of electric units or water units consumed by a consumer is depicted by an electric/water meter installed by the authorities. Readings have to be taken before and after counting period. For division of counting period into desirable intervals like hours, minutes etc. readings on these intervals has to be taken.

2. Printed Output: - This device prints the accumulated count at regular intervals on a roll of paper. Counter is set at zero at the start of a counting period. Time is directly linked to the local clock. Time of the day and no. of vehicles are printed side by side. This mechanism is programmed to give the count after the predefined interval of time.

3. Electronic System: - it is the modern system using electronic registering of data on Electronic storage devices such as Compact Discs, Mass storage devices. Now a days advanced systems are available which can be directly connected to computers through a port provide on the said system.

\subsection{Combination of Manual and Mechanical}

\section{Methods}

Due to certain constraints as in case of Heterogeneous Flow of traffic like India, Automatic methods are not effective because they are not. In order to increase the effectiveness of Census and making it less hassle free a combination of both the methods may be used. The assembly consists of a chart which moves at predefined intervals of time. When a particular switch/ pen is pressed representing a particular class of vehicle the pen on the channel on the chart identifies it with the arrival of that class of vehicle.

\subsection{Photographic Methods}

Photographic techniques were first used for Traffic study between Baltimore and Washington in $1927^{[9]}$. Greenshield who is regarded as one of the earliest pioneer in Traffic engineering was a proponent of Photographic methods. In 1933 he proposed the use of Photography method of Studying Traffic Behavior ${ }^{[10]}$.

Photographic Techniques can touch many important aspects of Traffic Engineering and also offer many benefits. It has virtually unlimited Potentialities and is a powerful tool which can be used for research as well as operational studies. These have many advantages:-

- Highly accurate data

- Limited use of manpower.

- Permanent record of Traffic Conditions

- Various Conditions on which Analysis is to be performed without having the need of going back to field

- Driver Behavior is unaffected by the study.(IOWA Department of Transport recommends extensively the mode of survey in which Road users especially Motorcyclists are not affected by the study ).

- Analysis can be easily done in the office by playing the Recorded Analysis on Monitor.

- These also have indirect benefits. It also can be used to identify violators.

In Modern Countries with advanced Traffic Engineering System, Big Screens are available in which minute details can be easily analyzed which also serve as a Standard Document for Enforcement of Rules and Regulations.

\section{METHODS OF TRAFFIC ANALYSIS}

\subsection{Indian Practice}

Methodology/Approach is based on the average of two week of Traffic Survey one in the Lean and other in harvesting Season as recommended by $\operatorname{IRC}^{\{\}}$. The survey is to be recorded in the field data sheet in the hourly manner in the Five Dash system which included Vertical Strokes for the first four vehicles which was followed by an Oblique Stroke for the Fifth Vehicle so as to depict a total of five. Census once complied, evaluated and analyzed serve as the Standard document for further evaluation.Accordingly Peak Hour Traffic is determined and then the requisite facility is evaluated as per this Peak Hour 


\subsubsection{Traffic Volume Study ${ }^{[1]}$}

Traffic volume Study is to be done on all the directions of Traffic movement 2 times for consecutive 7 days in Accordance with IRC ${ }^{[1]}$. The Traffic plying in India is of Heterogeneous in nature, therefore the equivalency factors as recommended by IRC is to be used for obtaining the desired PCU's.

Duration of Traffic Census: - The Traffic Census is to be carried out for 12 hours continuously at a stretch though with adequate time given to each Surveyor in rotation to have proper rest and food.

Abnormal Condition: - Abnormal Traffic condition if encountered at any instance during the survey, then Survey should be immediately called off. Abnormal conditions may arrive due to Diversion from or to the Control point, due to a state holiday or any other incident.

Recording of Data: - A field data Sheet as recommended by IRC $\{$ should be prepared for recording of data in Hourly manner.

Compiling of Data: - Data should be compiled immediately after the Survey and care should be taken to minimize errors and Omissions.

\subsection{U.K.Practice ${ }^{[6]}$}

The practice in United Kingdom is to measure the 7-day average flow for 16 hours (6am-10pm) in the month of August. Various Studies as well as past trends have yielded that in the month of August Average Travel Demand has been consistently the Highest. For Observations taken during any other month, Average Adjustment factors are applied to convert them to their August Equivalent.

\subsection{U.S.A Practice ${ }^{[7]}$}

Counts are carried on for 24 hours

Control Points Station:-Repeated Counts are made on a large number of Control points to obtain Seasonal and daily Traffic Characteristics and to obtain factors to convert these counts into daily average figures. Depending upon the importance of a Control point, there are Major and Minor Control Points. There are two types of counts recommended [Ref No.]

- Major Control Points:- Count on these Control points is carried out 12 times in an year i.e. in each month. Each count consists of 3 weekdays, one Saturday and One Sunday.

- Minor Control Points:-Counts on these Control Points is carried out four to six times in year, in alternate months, with each count covering a minimum of 48 hours on a week days.

\subsection{Iowa Department of Transport Practice ${ }^{[3]}$.}

This provides an easy method of measuring Congestion. There are several types and descriptions of traffic delay involving intersections. The type being addressed in this section is stopped-time delay, also known as stopped delay, which is the time that vehicles are waiting in line on the approach to an intersection. This study provides the Per cent of Vehicles Stopped, which is a useful indicator of signalized intersection performance.

\subsubsection{Procedure}

The field survey portion of the study includes the four highest consecutive fifteen-minute periods. Special care was taken, that the survey was conducted under normal conditions involving the weather, nearby traffic generator schedule, etc. Two observers are to be positioned on each leg, one to count and record the stopped vehicles at 15second intervals and the other to count the number of approach vehicles in 15-second intervals. The procedure is based on the assumption that each vehicle is stopped for the entire fifteen-second interval.

The observers should be strategically positioned so as to be able to see the entire approach. The observers' location and actions should be such that it doesn't distract the Road User especially motorists or influence their behavior.

Observers have to count those vehicles with locked wheels as being stopped as well as vehicles that had been stopped and are creeping forward in a queue that is not discharging.

\subsubsection{Method}

One observer will records the count of the number of stopped vehicles in each fifteen-second interval of time for each minute of the study time on Intersection Delay Study Field Sheet. The other observer will count the number of vehicles that stopped and the number that did not stop and give them to the first observer for recording in 15-minute intervals. A timing device with an audible cue at the 15second intervals is to be used so that it is not necessary for a member of the team to read a watch at each interval.

\section{RESULTS AT SANAT NAGAR/RAWALPORA INTERSECTION.}

Extensive Traffic survey was done at the Sanat Nagar/Rawalpora Intersection and analysis of the same was done which is depicted below:- 


\subsection{Intersection Approach Delay Study}

\begin{tabular}{|c|c|c|c|}
\hline \multicolumn{2}{|l|}{ TRAFFIC ON BARZULLA LEG } & \multicolumn{2}{|l|}{ TRAFFIC ON RAWALPORA LEG } \\
\hline $\begin{array}{l}\text { AVERAGE DELAY PER STOPPED } \\
\text { VEHICLE }\end{array}$ & 15 seconds & $\begin{array}{l}\text { AVERAGE DELAY PER STOPPED } \\
\text { VEHICLE }\end{array}$ & 15 seconds \\
\hline TOTAL DELAY & $\begin{array}{l}6960 \text { vehicle } \\
\text { seconds }\end{array}$ & TOTAL DELAY & $\begin{array}{l}7816 \text { vehicle } \\
\text { seconds }\end{array}$ \\
\hline $\begin{array}{l}\text { AVERAGE DELAY PER APROACH } \\
\text { VEHICLE }\end{array}$ & 12.04152249 & $\begin{array}{l}\text { AVERAGE DELAY PER APROACH } \\
\text { VEHICLE }\end{array}$ & 12.864 \\
\hline $\begin{array}{l}\text { PERCENTAGE OF VEHICLE } \\
\text { STOPPED }\end{array}$ & $80.27 \%$ & $\begin{array}{l}\text { PERCENTAGE OF VEHICLE } \\
\text { STOPPED }\end{array}$ & $85.556149 \%$ \\
\hline TRAFFIC ON HYDERPORA LEG & & TRAFFIC ON NOWGAM LEG & \\
\hline $\begin{array}{l}\text { AVERAGE DELAY PER STOPPED } \\
\text { VEHICLE }\end{array}$ & 15 seconds & $\begin{array}{l}\text { AVERAGE DELAY PER STOPPED } \\
\text { VEHICLE }\end{array}$ & 15 seconds \\
\hline TOTAL DELAY & $\begin{array}{l}8436 \text { vehicle } \\
\text { seconds }\end{array}$ & TOTAL DELAY & $\begin{array}{l}12547 \text { vehicle } \\
\text { seconds }\end{array}$ \\
\hline $\begin{array}{l}\text { AVERAGE DELAY PER APROACH } \\
\text { VEHICLE }\end{array}$ & 12.7289 & $\begin{array}{l}\text { AVERAGE DELAY PER APROACH } \\
\text { VEHICLE }\end{array}$ & 14.98 \\
\hline $\begin{array}{l}\text { PERCENTAGE OF VEHICLE } \\
\text { STOPPED }\end{array}$ & $84.86 \%$ & PERCENTAGE OF VEHICLE STOPPED & $99.93 \%$ \\
\hline
\end{tabular}

\begin{tabular}{ll}
\hline AVERAGE TRAFFIC & \\
\hline AVERAGE DELAY PER STOPPED VEHICLE & RESULT \\
AVERAGE DELAY & 8939.75 vehicle seconds \\
AVERAGE DELAY PER APROACH VEHICLE & 13.1536 \\
PERCENTAGE OF VEHICLE STOPPED & $87.654 \%$ \\
\hline
\end{tabular}

\subsection{Consolidated Average Daily Traffic.}

The whole data is consolidated as Average of the Survey Conducted both in Lean as well as Harvesting Season and accordingly Peak Hour is determined from this data. The
Composition of all the lanes as well as turning movements are determined and depicted so as to be in a position of development of Intelligent Design of the intersection.

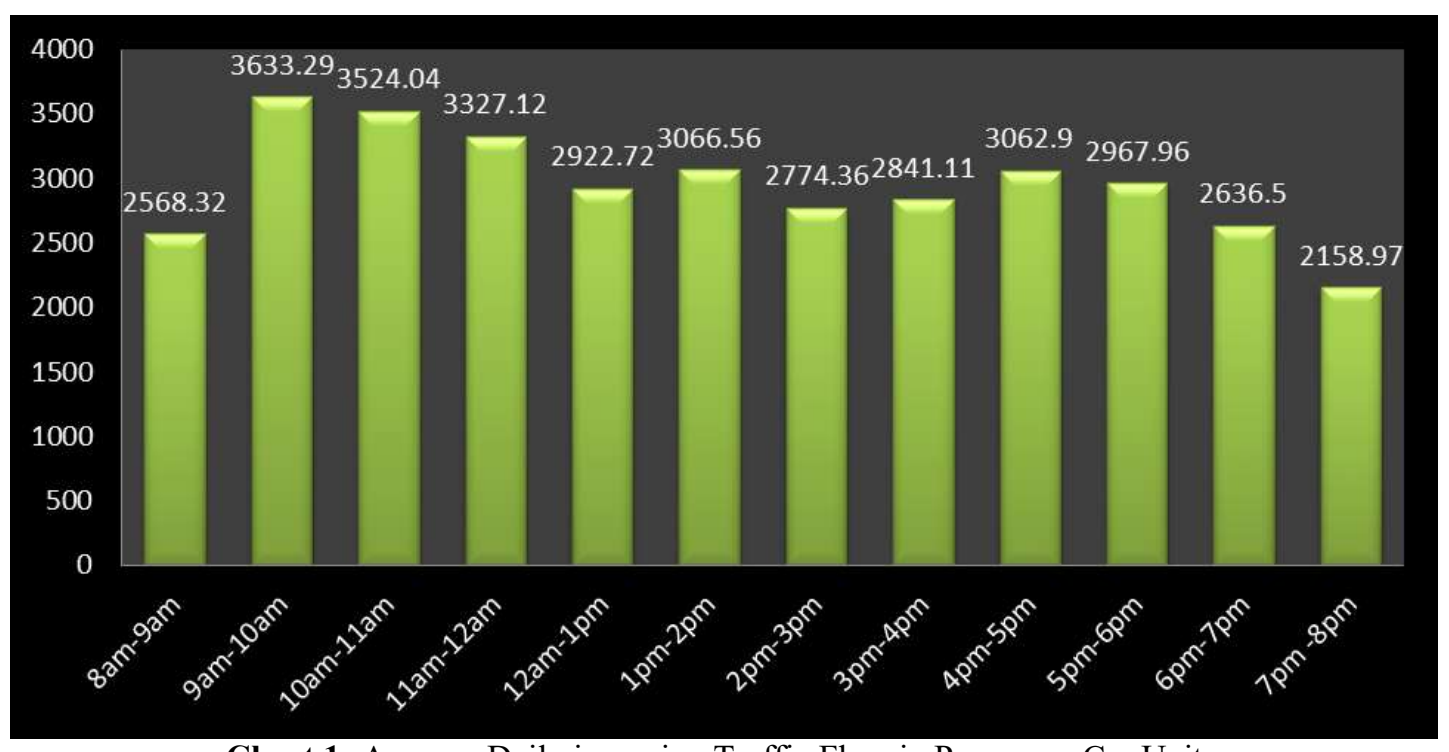

Chart 1: Average Daily incoming Traffic Flow in Passenger Car Units 
Intersection Design Data

Intersection Design Data Peak Hour 9 a.m Hrs. To 10 a.m Hrs Peak Hour Design Traffic

Name \& Location of Intersection_Sanat Nagar/Rawalpora Intersection.

National Highway $1 \mathrm{~A}$ Bypass, Srinagar, Kashmir.

\begin{tabular}{|c|c|c|c|c|c|c|c|c|}
\hline \multirow{3}{*}{$\begin{array}{l}\text { Entering } \\
\text { Type }\end{array}$} & \multirow{2}{*}{\multicolumn{3}{|c|}{$\frac{\text { From }}{\text { Leg B }^{\text {RWALPORA }}}$}} & \multicolumn{5}{|c|}{$\operatorname{Lcg} \Lambda^{*} \quad$ HYDERPORA } \\
\hline & & & & \multicolumn{2}{|c|}{ NQWGAM } & \multicolumn{2}{|c|}{ BARZDLLA } & \multirow[t]{2}{*}{ Remarks } \\
\hline & Nos & $\begin{array}{l}\text { PCU } \\
\text { Equi- } \\
\text { valency }\end{array}$ & $\mathrm{PCU}$ & Nos & $\begin{array}{l}\text { PCU } \\
\text { Equi- } \\
\text { valency }\end{array}$ & Nos & $\begin{array}{l}\text { PCU } \\
\text { Equi- } \\
\text { valency } \\
\end{array}$ & \\
\hline & 1 & 2 & $3=1 \times 2$ & 1 & 2 & 1 & 2 & \\
\hline $\begin{array}{l}\text { Fast Vehicles } \\
\text { 1. Passenger cars, tempos } \\
\text { auto rickshaw, tractors, } \\
\text { pickup vans } \\
\text { 2. Motor Cycles, scooters } \\
\text { 3. Agricultrual tractor Light } \\
\text { Commercial Vehicles } \\
\text { 4. Trucks, Buses, } \\
\text { 5. Tractor-Trailer, Truck } \\
\text { Trailer units }\end{array}$ & $\begin{array}{c}71.16 \\
13.95 \\
28.453 \\
8.556\end{array}$ & $\begin{array}{l}1.00 \\
\\
0.50 \\
1.50 \\
9 \\
3.00 \\
4.50\end{array}$ & & $\begin{array}{l}240.192 \\
41.37 \\
201.82 \\
48.484\end{array}$ & 2 & $\begin{array}{l}54.48 \\
5.076 \\
4.89 \\
1.8187\end{array}$ & & \\
\hline $\begin{array}{l}\text { Slow Vehicles } \\
\text { 6. Cycles } \\
\text { 7. Cycle Rickshaws } \\
\text { 8. Hand Cart } \\
\text { 9. Horse Drawn } \\
\text { 10. Bullock-Carts }\end{array}$ & 2.79 & \begin{tabular}{|l|}
0.50 \\
1.50 \\
3.00 \\
4.00 \\
8.00
\end{tabular} & & 5.16 & & 0.2 & & \\
\hline TOTAL VEHICLES & $=732$ & 5098 & & & DTAL & CU's & $=1291$. & 7348 \\
\hline
\end{tabular}

Chart 2: Intersection Design Data for Hyderpora Leg as recommended by IRC $^{[2]}$

Intersection Design Data

Intersection Design Data Peak Hour 9 a.m Hrs. To 10 a.m Hrs Peak Hour Design Traffic

Name \& Location of Intersection_Sanat Nagar/Rawalpora Intersection.

National Highway $1 \mathrm{~A}$ Bypass, Srinagar, Kashmir.

\begin{tabular}{|c|c|c|c|c|c|c|c|c|}
\hline \multirow{3}{*}{$\begin{array}{l}\text { Entering } \\
\text { Type }\end{array}$} & \multirow{2}{*}{\multicolumn{3}{|c|}{$\frac{\text { From }}{\text { RAAWALPORA }}$}} & \multicolumn{5}{|c|}{$\operatorname{Lcg} \Lambda^{*}$ NOWGAM } \\
\hline & & & & \multicolumn{2}{|c|}{ HYDERPORA } & \multicolumn{2}{|c|}{ BARZVLLLA } & \multirow[t]{2}{*}{ Remarks } \\
\hline & Nos & $\begin{array}{l}\text { PCU } \\
\text { Equi- } \\
\text { valency }\end{array}$ & $\mathrm{PCU}$ & Nos & $\begin{array}{l}\text { PCU } \\
\text { Equi- } \\
\text { valency }\end{array}$ & Nos & $\begin{array}{l}\text { PCU } \\
\text { Equi- } \\
\text { valency }\end{array}$ & \\
\hline & 1 & 2 & $3=1 \times 2$ & 1 & 2 & 1 & 2 & \\
\hline $\begin{array}{l}\text { Fast Vehicles } \\
\text { 1. Passenger cars, tempos } \\
\text { auto rickshaw, tractors, } \\
\text { pickup vans } \\
\text { 2. Motor Cycles, scooters } \\
\text { 3. Agricultrual tractor Light } \\
\text { Commercial Vehicles } \\
\text { 4. Trucks, Buses, } \\
\text { 5. Tractor-Trailer, Truck } \\
\text { Trailer units }\end{array}$ & $\begin{array}{l}52.72 \\
16.124 \\
33.311 \\
3.5813\end{array}$ & $\begin{array}{l}1.00 \\
\\
0.50 \\
1.50 \\
3.00 \\
\\
4.50\end{array}$ & & $\begin{array}{l}239.08 \\
29.97 \\
\\
201.85 \\
18.6739\end{array}$ & & $\begin{array}{l}231.952 \\
28.31 \\
18.6739 \\
21.0534\end{array}$ & & \\
\hline $\begin{array}{l}\text { Slow Vehicles } \\
\text { 6. Cycles } \\
\text { 7. Cycle Rickshaws } \\
\text { 8. Hand Cart } \\
\text { 9. Horse Drawn } \\
\text { 10. Bullock-Carts }\end{array}$ & 3.1 & $\begin{array}{l}0.50 \\
1.50 \\
3.00 \\
4.00 \\
8.00\end{array}$ & & 4.97 & & 1.68 & & \\
\hline TOTAL & $\mathrm{HICL}$ & $E S=9$ & 5.890 & & DTAL P & CU'S & $=1581$. & 7658 \\
\hline
\end{tabular}

Chart 3: Intersection Design Data for Nowgam Leg as recommended by IRC $^{[2]}$
Intersection Design Data

Intersection Design Data Peak Hour 9 a.m Hrs. To 10 a.m Hrs Peak Hour Design Traffic

Name \& Location of Intersection Sanat Nagar/Rawalpora Intersection.

National Highway $1 \mathrm{~A}$ Bypass, Srinagar, Kashmir.

\begin{tabular}{|c|c|c|c|c|c|c|c|c|}
\hline \multirow{3}{*}{$\begin{array}{l}\text { Entering } \\
\text { Type }\end{array}$} & \multirow{2}{*}{\multicolumn{3}{|c|}{$\frac{\text { From }}{\text { LegYRERPORA }}$}} & \multicolumn{5}{|c|}{$\operatorname{Leg} A^{*}$ RAWALPORA } \\
\hline & & & & \multicolumn{2}{|c|}{ NQWG GAM } & \multicolumn{2}{|c|}{ BARZLDLLA } & \multirow[t]{2}{*}{ Remarks } \\
\hline & Nos & $\begin{array}{l}\text { PCU } \\
\text { Equi- } \\
\text { valency }\end{array}$ & PCU & Nos & $\begin{array}{l}\text { PCU } \\
\text { Equi- } \\
\text { valency }\end{array}$ & Nos & $\begin{array}{l}\mathrm{PCU} \\
\text { Equi- } \\
\text { valency }\end{array}$ & \\
\hline & 1 & 2 & $3=1 \times 2$ & 1 & 2 & 1 & 2 & \\
\hline $\begin{array}{l}\text { Fast Vehicles } \\
\text { 1. Passenger cars, tempos } \\
\text { auto rickshaw, tractors, } \\
\text { pickup vans } \\
\text { 2. Motor Cycles, scooters } \\
\text { 3. Agricultrual tractor Light } \\
\text { Commercial Vehicles } \\
\text { 4. Trucks, Buses, } \\
\text { 5. Tractor-Trailer, Truck } \\
\text { Trailer units }\end{array}$ & $\begin{array}{l}138.09 \\
35.828 \\
14.638 \\
9.504\end{array}$ & $\begin{array}{l}0.50 \\
1.50 \\
\\
3.00 \\
\\
4.50\end{array}$ & & $\begin{array}{l}50.876 \\
4.134 \\
43.914 \\
1.782\end{array}$ & & $\begin{array}{l}348.86 \\
77.168 \\
27.042 \\
35.64\end{array}$ & & \\
\hline & & & & & & & & \\
\hline $\begin{array}{l}\text { Slow Vehicles } \\
\text { 6. Cycles } \\
\text { 7. Cycle Rickshaws } \\
\text { 8. Hand Cart } \\
\text { 9. Horse Drawn } \\
\text { 10. Bullock-Carts }\end{array}$ & 14.4 & $\begin{array}{l}0.50 \\
1.50 \\
3.00 \\
4.00 \\
8.00\end{array}$ & & 0 & & 1.6 & & \\
\hline TOTAL VEHICLES & $=821$. & 464 & & TC & DTAL & CU'S = & $=1022$. & 903 \\
\hline
\end{tabular}

Chart 4: Intersection Design Data for Rawalpora Leg as recommended by IRC ${ }^{[2]}$

Intersection Design vata

Intersection Design Data Peak Hour Design Traffic

Peak Hour 9 a.m Hrs. To 10 a.m Hrs

Name \& Location of Intersection Sanat Nagar/Rawalpora Intersection.

National Highway $1 \mathrm{~A}$ Bypass, Srinagar, Kashmir.

\begin{tabular}{|c|c|c|c|c|c|c|c|c|}
\hline \multirow{3}{*}{$\begin{array}{l}\text { Entering } \\
\text { Type }\end{array}$} & \multirow{2}{*}{\multicolumn{3}{|c|}{$\begin{array}{l}\text { From } \\
\text { Leg BERPORA }\end{array}$}} & \multicolumn{5}{|c|}{$\operatorname{Leg} \Lambda^{*} \quad$ BARZULLA } \\
\hline & & & & \multicolumn{2}{|c|}{ NQWEGAM } & \multicolumn{2}{|c|}{ RALEGLPORA } & \multirow[t]{2}{*}{ Remarks } \\
\hline & Nos & $\begin{array}{l}\text { PCU } \\
\text { Equi- } \\
\text { valency }\end{array}$ & $\mathrm{PCU}$ & Nos & $\begin{array}{l}\text { PCU } \\
\text { Equi- } \\
\text { valency }\end{array}$ & Nos & $\begin{array}{l}\text { PCU } \\
\text { Equi- } \\
\text { valency }\end{array}$ & \\
\hline & 1 & 2 & $3=1 \times 2$ & 1 & 2 & 1 & 2 & \\
\hline $\begin{array}{l}\text { Fast Vehicles } \\
\text { 1. Passenger cars, tempos } \\
\text { auto rickshaw, tractors, } \\
\text { pickup vans } \\
\text { 2. Motor Cycles, scooters } \\
\text { 3. Agricultrual tractor Light } \\
\text { Commercial Vehicles } \\
\text { 4. Trucks, Buses, } \\
\text { 5. Tractor-Trailer, Truck } \\
\text { Trailer units }\end{array}$ & $\begin{array}{l}58.144 \\
89.646 \\
\\
6.756 \\
5.94\end{array}$ & $\begin{array}{l}1.00 \\
\\
0.50 \\
1.50 \\
3.00 \\
4.50\end{array}$ & & $\begin{array}{l}101.75 \\
8.268 \\
15.764 \\
4.752\end{array}$ & & $\begin{array}{l}29.072 \\
2.756 \\
4.505, \\
1.782\end{array}$ & & \\
\hline $\begin{array}{l}\text { Slow Vehicles } \\
\text { 6. Cycles } \\
\text { 7. Cycle Rickshaws } \\
\text { 8. Hand Cart } \\
\text { 9. Horse Drawn } \\
\text { 10. Bullock-Carts }\end{array}$ & 1.44 & $\begin{array}{l}0.50 \\
1.50 \\
3.00 \\
4.00 \\
8.00\end{array}$ & & 1.8 & & 0.36 & & \\
\hline TOTAL VEHICLES & $=252$. & 737 & & & DTAL F & CU'S = & $=319.6$ & \\
\hline
\end{tabular}

Chart 5: Intersection Design Data for Barzulla Leg as recommended by IRC $^{[2]}$ 


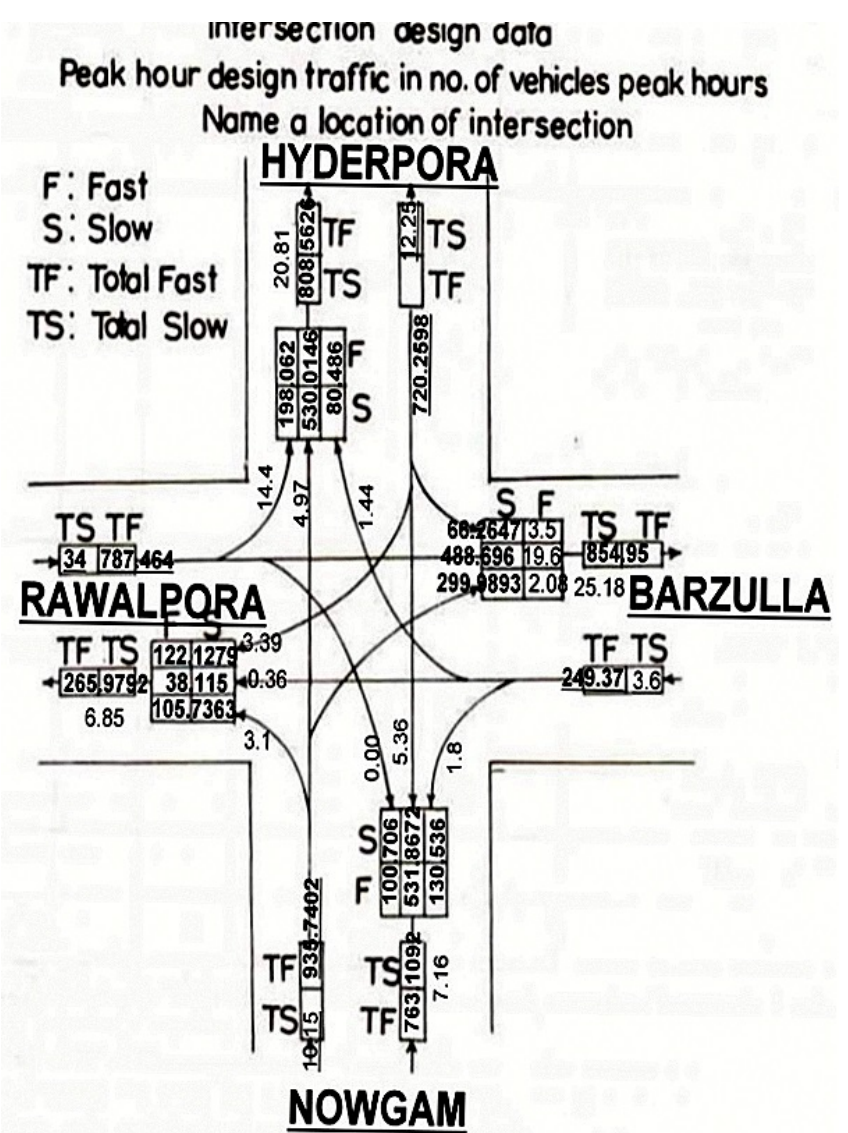

Chart 6: Intersection Design Data Peak Hour Design Vehicle as recommended by IRC ${ }^{[2]}$

\section{THE DISCUSSION}

Photographic methods are the most suitable for maintaining high accuracy as these video tapes are analyzed in the office calmly with relative ease. This tapes can be analyzed many times, so if at all there is any kind of error it can easily be rectified and reconnaissance of earlier work can be done at any given moment of time. Automatic methods present the most inaccurate data, as when a vehicle with more than one axle passes over the selected section of the road, results in recording of the inaccurate result. This is of significance only when there are large no. of vehicle having more than two axles present in the traffic flow. It cannot detect different lanes of vehicle or their corresponding different maneuvers. Moreover it is likely to get damaged by crawler tractor, tire chain, snow ploughs and other similar equipment's. In case of photoelectric type of censor obstruction may be caused by pedestrian or more than one vehicle in different traffic lanes may be present but positioned in the line of beam simultaneously, which will result in recording of inaccurate data. In case of Manual Counts if trained professional are not employed they present the worst data in terms of accuracy or if less number of people are employed, but in actual practice it rarely occurs. In case of Combination of manual and automatic methods, the flaw of automatic methods is overcome with the hassle free mechanism of automaticity but precision is not of the same scale as that of Photographic methods.
In terms of tabulation of data Automatic methods are the simplest as the count is either directly given in the form of output (either soft copy of the hard copy). Automatic are followed by Combination of Manual and Automatic. Manual may take a longer time to tabulate if not done in five Dash System, but still with respect to former it is time consuming. Photographic methods are cumbersome to tabulate as they required to be tabulated by counting in the office (Census is done by recording of traffic volume on video tapes, then counting the same in the office will be regarded as tabulation).

Photographic Methods are the most versatile as these can be used in any type of terrain, flow conditions be it Heterogeneous or homogenous, irrespective of distance between the control points, topography. Automatic methods are the least versatile as these cannot be used for heterogeneous Flow conditions or its mechanism being influenced by other factor e.g. Magnetism mechanism ,damaging by crawler tractor, tire chain, snow ploughs and other similar equipment's may also occur. Combination of Manual and Automatic methods may get affected if there is a large variation in different class of vehicles. Manual Methods are not viable where control point is near two intersections very close to each other, distracting the line of sight, however such condition rarely occurs.Photographic Equipment are the most expensive in purchasing as well as maintenance, followed by Automatic Methods, combination of both the two. Manual methods are the cheapest of all but need supervision.

U.K practice is based on designing the facility for the highest flow occurring in an year whereas Indian Practice is to design a facility for the average Flow occurring in the year which is done by taking the average of the Highest flow and lowest flow occurring in the year. By doing so the facility is able to suffice itself during the majority of the year with due considerations to economy as India being a Developing Country with a low Standard of living as compared to U.K. or U.S.A. The U.S.A practice is to measure the traffic flow every month for Major points whereas for minor Roads measure the same in 4-6 times in ayear. By this way seasonal variation is measured accurately which is then used for designing of the particular facility. U.S.A and U.K methods are therefore best approaches for the purpose of design, improved L.O.S, thus evolvement of design which will suffice through the maximum incoming flow. U.S.A method provides a wider data which can be used for all the Traffic Management operations, like the time of period for maintenance, time period of diversion to or from, percentage of different class of vehicles using the particular section at different time period and requisite measures to be taken. In case of Sanat Nagar/ Rawalpora Intersection many Accidents (Fatal as well as Non-Fatal) have taken place during 8.00 p.m. to 8.00 a.m., during which survey was not undertaken. For a country such as India in which urban areas are moving from being developing to being developed introspection of Standards (methods) is now inevitable. 


\section{SUMMARY AND CONCLUSION}

Census method is based on type of accuracy, economy, and method of evaluation of a particular place. .Different methods of analysis with respect to economic consideration, L.O.S required, Standard of living of people, local practice as well as type of Flow. Different methods of traffic Census described, their order as per Accuracy can be enlisted as:-

1. Photographic Method

2. Combination of Manual and automatic Method

3. Manual Method4. Automatic Method

However, with respect to tabulation, Documentation the order can be enlisted as:-

1. Automatic Method

2. Combination of Manual and Automatic Method

3. Manual Method

4. Photographic Methods

As per Versatility, the order can be enlisted as:-

1. Photographic Methods

2. Manual Method

3. Combination of Manual and Automatic method

4. Automatic Method

The order with respect to economic considerations can be enlisted as:-

1. Manual Methods

2. Combination of Manual and Automatic method

3. Automatic Method

4. Photographic Method

The order with respect to Method of Analysis can be enlisted as:-

1. U.S.A Method

2. U.K Method

3. IRC Method

IOWA Department of transport guidelines provide a simplified manner in which Congestion can be measured, thereby depicting the level of analysis to be done as well as priority of analysis, They give us an idea about the loss suffered to economy be it in the form of Time lost, increased Vehicle operating cost, Fuel cost as all these are directly linked to the level of congestion. It can also be used as a scale to showcase the necessity of up gradation or benefits by comparing level of Congestion before and after on IOWA Department of Transport Scale.

IRC $^{[1]}$ in which survey is recommended for seven consecutive days for 12 hours, one weekday and an off day, a full 24 hours survey should be comprehended which will give an idea about flow taking place during the whole day and then requisite Traffic Management operations can be undertaken based on this. Decisions with respect to Maintenance operations like feasibility of time (during a year or even during the 24 hours interval) as well as necessary measures to be taken. For the type of maintenance operations to be allowed while the present roadway is functional, it is imperative full data with respect to flow for full 24 hours is available. Sometimes class of vehicles using the facility or the flow is comparatively high that proper diversions routes are to be sought out. In some cases alternate facility to which traffic may be diverted may not be able to cater the demand and thus may lead to congestion.

\section{REFERENCES}

[1] IRC-9-1972,Manual on "Traffic Census on Roads", National Highway Authority of India(NHAI),Ministry of Surface Transport, The Indian Road Congress (IRC) publication09,New Delhi, 1972.

[2] IRC-SP41-1994,Manual on "Guidelines for the Design of At-Grade Intersection in Rural \& Urban Areas", National Highway Authority of India(NHAI),Ministry of Surface Transport, The Indian Road Congress (IRC)Special publication41,New Delhi,1994.

[3] Traffic \& safety Manual on "Intersection Delay Study",lowa Department of Transportation, Office of traffic \& Safety ,issued on 19-02-07.

[4] Dr.L.R.Kadiyali, "Traffic Engineering and Highway Transport Planning", Khanna Publishers, Daryaganj, New, New Dehli, 8th Edition $3^{\text {rd Reprint } 2014 .}$

[5] Tom V.Mathew, "Transportation Engineering I ", Transportation Systems Engineering, Civil Engineering Department, Indian Institute of Technology Bombay, Powai, Mumbai 400076, India,Jan-May 2006.

[6] Traffic prediction, Ministry of Transport (U.K), Her Majesty's Stationary Office, London, 1968.

[7] Traffic Counting Classification and weighing, U.S.Bureau of Public Roads, Washington, 1957

[8] Master Plan , Srinagar Metropolitan Area 2021, Government of Jammu and Kashmir, Town Planning Organization, Kashmir.

[9] Johnson, A.N.,Maryland Aerial Traffic density survey, Proceedings, Highway Research Board, 7(1). Washington, 1927.

[10] Greenshields, B.D., The Photographic method of Studying Traffic Behavior,Proceedings, Highway Research Board, Vol. 13. Washington, 1933.. 